\title{
Changes in equine endometrial oestrogen receptor $\alpha$ and progesterone receptor $m R N A s$ during the oestrous cycle, early pregnancy and after treatment with exogenous steroids
}

\author{
K. J. McDowell, M. H. Adams, C. Y. Adam and K. S. Simpson \\ Department of Veterinary Science, Maxwell H Gluck Equine Research Center, University of Kentucky, \\ Lexington, KY 40546-0099, USA
}

\begin{abstract}
Two experiments were performed to determine changes in the abundance of oestrogen and progesterone receptor ( $E R \alpha$ and $P R$ ) mRNAs in equine endometrium during the oestrous cycle and early pregnancy, and under the influence of exogenous steroids. In Expt 1, endometrial biopsies were obtained from non-mated mares during oestrus and at days 5, 10 and 15 after ovulation, and from pregnant mares at days 10,15 and 20 after ovulation. There were overall effects of day on the abundance of $\operatorname{ER} \alpha(P=0.0001)$ and $\operatorname{PR}(P=0.0014)$ mRNAs. The amount of ER $\alpha$ mRNA decreased at day 10 of pregnancy, and PR mRNA was reduced at day 5 in non-mated mares and at day 15 of pregnancy, compared with oestrous values. Experiment 2 was conducted to determine the effects of exogenous steroids on endometrial ER $\alpha$ and PR mRNAs. Endometrial biopsies were obtained from 19 anoestrous mares that had been treated with vehicle, oestradiol, progesterone, or oestradiol followed by progesterone for either a short or a long duration. The steroid treatment affected the abundance of ER $\alpha$ mRNA $(P=0.0420)$, which was higher $(P<0.05)$ in the oestradiol group than in the group treated with oestradiol followed by long duration progesterone. The steroid treatment did not affect the abundance of PR mRNA. These results demonstrate that the amount of steroid receptor mRNA changes with the fluctuating steroid environment in the uterine endometrium of cyclic and early pregnant mares, and that the duration of progesterone dominance may affect ER $\alpha$ gene expression. In addition, factors other than steroids may regulate ER $\alpha$ and PR gene expression in equine uterine endometrium.
\end{abstract}

\section{Introduction}

Oestrogens and progestins co-ordinate many reproductive events, including complex physical and behavioural changes associated with mating, pregnancy, parturition and lactation (Ing et al., 1993). Steroid hormones are critical regulators of development, cell differentiation, morphogenesis and organ physiology (Mangelsdorf et al., 1995). The major effect of steroid hormone binding in target tissues is to increase the rate of transcription in the response gene (Parker, 1990; Mangelsdorf et al., 1995; King, 1997). Oestrogens and progestins autoregulate production of their own receptors (ER and PR, respectively), as well as those of each other in many systems.

Several studies showed that the concentrations of both oestradiol and progesterone receptor proteins in the mare endometrium increased at oestrus and early dioestrus and decreased by mid- to late dioestrus (Bracher et al., 1991; Tomanelli et al., 1991; Watson et al., 1992). During oestrus, stromal cells stained more intensely for ER and PR proteins than luminal or glandular epithelial cells or myometrial cells.

Received 23 November 1998.
During dioestrus, staining for both types of receptor tended to decrease in stromal and myometrial cells, while staining in epithelial cells was not affected by the stage of the oestrous cycle (Watson et al., 1992). Although ER and PR proteins have been examined in equine endometrium by immunocytochemistry, information regarding control of gene expression at the level of the mRNA is lacking. Information on how the abundance of both mRNA and protein fluctuate is required to gain a more complete understanding of the control of steroid receptor gene expression. For example, in some systems, such as during the preovulatory oestrogen surge in ewes, increases in endometrial ER mRNA precede increased ER protein production (Ott et al., 1993), and upregulation of ER gene expression is thought to be regulated primarily by post-transcriptional mechanisms (Ing et al., 1993).

Adams et al. (1997) cloned both the equine ER $\alpha$ and PR CDNAs to gain a better understanding of mechanisms of oestrogen and progesterone action in horses and to examine regulation of gene expression of these receptors in equine reproductive tissues. The present study was designed to examine two aspects of the control of ER and PR gene expression: (i) that the adundance of receptor mRNA 
changes as steroid concentrations vary naturally during the oestrous cycle and early pregnancy; and (ii) the effect of steroid supplementation during anoestrus on the abundance of receptor mRNA. Parts of this study were presented in preliminary form (Adams et al., 1997).

\section{Materials and Methods}

\section{Animals and experimental design}

For Expt 1, 25 normally cyclic light horse mares (Equus caballus) of known fertility were used over two breeding seasons (April-September). Mares were of mixed breeding, weighed approximately $400-500 \mathrm{~kg}$, and were maintained on grass pasture with free access to water. Over the two seasons, 42 samples were collected; some mares were used in both breeding seasons. Mares were palpated per rectum, and the reproductive tracts were examined by real-time ultrasonography (Tokyo-Keiki LS1000 with a $5 \mathrm{MHz}$ probe; Products Group International, Lyons, $\mathrm{CO}$ ) every 2-3 days until a follicle $>30 \mathrm{~mm}$ in diameter was detected. Mares were then teased with a stallion and palpated and examined by ultrasonography once a day during oestrus until ovulation was detected (day 0 ). For the groups of pregnant mares, mares were mated every other day to a stallion of proven fertility by artificial insemination from the time a follicle $>30$ $\mathrm{mm}$ was detected until ovulation was detected. Both mated and non-mated mares were checked via ultrasonography at least twice a week after ovulation to determine whether a second ovulation had occurred or to check for the presence of a conceptus vesicle. If a second ovulation occurred, or if no conceptus vesicle was observed in mated mares by day 12 after ovulation, the mares received a luteolytic dose of $\mathrm{PGF}_{2 \alpha x}$ (10 mg i.m.; Lutalyse, Upjohn Co, Kalamazoo, MI) and were used on a subsequent oestrous cycle. Endometrial biopsies were taken from non-mated mares during behavioural oestrus and at days 5,10 and 15 after ovulation, and from pregnant mares at days 10,15 and 20 after ovulation $(n=6$ mares per day). Two tissue samples were taken from each mare, one from each uterine horn, approximately at the bifurcation of the uterine horn and uterine body. The two samples from each mare were combined and frozen immediately on dry ice. A blood sample was obtained from each mare via jugular venepuncture immediately before biopsy.

For Expt 2, 19 mares that had become anoestrus (December) were examined by ultrasonography and determined to have no follicles $>15 \mathrm{~mm}$ in diameter and no observable luteal tissue. The mares were given two injections of $\mathrm{PGF}_{2 \alpha}(10 \mathrm{mg}$ i.m.) 14 days apart to cause regression of any undetected luteal tissue. Three days after the second injection, the reproductive tracts were examined by real-time ultrasonography and mares were randomly assigned to one of the following five treatment groups: control (vehicle (safflower oil) for 1 day); oestradiol alone (oestradiol 17valerate, $5 \mathrm{mg} \mathrm{day}^{-1}$ for 6 days); progesterone alone $(250 \mathrm{mg}$ day $^{-1}$ for 6 days); oestradiol and short duration progesterone (oestradiol for 6 days followed by progesterone for 6 days); oestradiol and long duration progesterone (oestradiol for 6 days followed by progesterone for 12 days). The control group, treated for 1 day before sampling, represented the 'baseline' on which the remaining treatments were imposed. Treatments were administered i.m. once a day between 07:00 and 09:00. Four mares were assigned to each group, except for the control group in which there were three mares. Blood samples were obtained by jugular venepuncture immediately before the first hormone treatment, and every $6 \mathrm{~h}$ for 24 $h$ on the final day of treatment. Endometrial biopsies were taken from each mare, as described earlier, immediately after the final blood sample.

Serum from both experiments was stored frozen at $-20^{\circ} \mathrm{C}$ until assayed, and all biopsies were stored at $-80^{\circ} \mathrm{C}$ until RNA extraction. Both experiments were approved by the University of Kentucky Institutional Animal Care and Use Committee.

\section{Cloning the equine oestrogen and progesterone receptor cDNAs}

The equine oestrous endometrial cDNA library of Adams et al. (1997) was screened for equine (e)ER cDNA with a rat ER CDNA probe representing the hormone binding domain (HBD), and five positive clones were isolated. Plasmids were prepared by the alkaline lysis method (Morelle, 1989) and cDNA inserts were excised from the plasmids using the restriction enzymes Eco $\mathrm{RI}$ and Xho I. Each resulting CDNA insert was approximately 4000 bp in length, as estimated by agarose gel electrophoresis and ethidium bromide staining. PCR primers were designed from the rat ER (GenBank accession no. X61098, National Center for Biotechnology Information, Bethesda, MD) to obtain a shorter-length fragment to use as a probe in ribonuclease protection assays (RPA). A PCR reaction was performed using one of the equine ER clones (eER13) as a template; the resulting $415 \mathrm{bp}$ PCR product encompassed the majority of the HBD. One microlitre of the PCR product was then ligated directly into the PCR-II vector (TA Cloning Kit, Invitrogen, Carlsbad, CA). Plasmids were transformed into bacterial cells (Top-10F'; Invitrogen) and positive colonies were identified by blue-white screening. Five plasmids were prepared by the alkaline lysis method, and the cDNA inserts were sequenced to confirm the presence of the majority of the eER HBD (Sequenase Version 2.0; Amersham, Arlington Heights, IL). The resulting cDNA sequence of the eER HBD was compared with nucleotide sequences of the human, rat, mouse and sheep ER cDNAs (GenBank accession nos X03635, X61098, M38651 and Z49257, respectively). One of these plasmids, containing the majority of the eER HBD (eER13.1), was used as a template to synthesize a probe for RPA.

The equine oestrous endometrial cDNA library was also screened for ePR, using the methods described earlier, except that the rat PR HBD CDNA was used to synthesize the probe. Seven positive clones were identified, plasmids were prepared, and cDNA inserts were excised from the plasmids. The resulting $\mathrm{ePR} c \mathrm{CNN}$ As ranged in size from approximately 1200 to $4000 \mathrm{bp}$, as estimated by agarose gel electrophoresis and ethidium bromide staining. PCR primers were designed from the rat PR (GenBank accession no. S64044) to amplify 
$354 \mathrm{bp}$ of the HBD, and a PCR reaction was performed using one of the equine PR clones (ePR3) as a template. The PCR product was purified by agarose gel electrophoresis. The DNA was removed from the gel with Geneclean III (Bio 101, Vista, CA), cloned into the pCR Script vector, and transformed into XL1 Blue MRF' bacterial cells (Stratagene, La Jolla, CA). Positive colonies were identified by blue-white screening, and ten plasmids were purified as described earlier. The HBDs were sequenced from one of these clones (ePR3.3), as well as from ePR3. The sequences were compared with those of human, mouse, rabbit, rat and sheep PR HBD cDNAs, (GenBank accession nos X51730, M68915, X06623, L16922 and U30300, respectively). The ePR3.3 clone, containing the majority of the HBD, was used as a template to prepare the probe for RPA. In addition, the 5 ' end of the longest ePR clone (ePR7, approximately $4000 \mathrm{bp}$ ) was sequenced as described earlier to confirm the presence of translation initiation sites.

\section{Ribonuclease protection assay}

Total RNA was isolated from all tissue samples by the method of Chomczynski and Sacchi (1987). The eER and ePR mRNA transcripts were faint and not detectable consistently in RNA from equine endometrium in preliminary studies using northern blotting. Therefore, RPAs were developed to determine the steady state amount of mRNA for the receptors in equine endometrium.

Plasmid containing the eER HBD cDNA (eER13.1) was purified by fast protein liquid chromatography (FPLC) and was linearized with the restriction enzyme Hha I. An eER antisense cRNA probe (500 ng linearized plasmid containing the eER HBD cDNA, labelled with [ $\alpha^{32}$ P]UTP to a specific activity of $9.8 \times 10^{7}$ d.p.m. $\mu g^{-1}$ cRNA), designed to protect a 324 nucleotide fragment, was synthesized by in vitro transcription (Davis et al., 1994). A human 18S rRNA control template (500 ng pTri RNA 18S; Ambion, Austin, TX) was labelled in a similar manner to yield a probe (specific activity $5.7 \times 10^{6}$ d.p.m. $\mu \mathrm{g}^{-1}$ cRNA) designed to protect an 80 nucleotide fragment of the $18 \mathrm{~S}$ rRNA. This template, which contains a highly conserved region of the $18 \mathrm{~S}$ ribosomal gene, was used as an internal control for errors in sample handling, since its expression was not expected to fluctuate in endometrial RNA samples among treatment groups. The cRNA probes were purified by electrophoresis through nondenaturing polyacrylamide gels, and RPA was performed by standard methods (Davis et al., 1994). Briefly, labelled eER (3 $\times 10^{5}$ d.p.m. $)$ and $18 \mathrm{~S}\left(1 \times 10^{5}\right.$ d.p.m. $)$ cRNAs were combined together with $10 \mu \mathrm{g}$ endometrial total RNA and allowed to hybridize at $52^{\circ} \mathrm{C}$ overnight. The cRNA probes were also hybridized with $10 \mu \mathrm{g}$ yeast tRNA to serve as a negative control in the RPA assays. RNase T1 (1.75 ng $\mu^{-1}$; Gibco BRL, Grand Island, NY) was used to digest non-hybridized RNAs. The resulting undigested transcripts were subjected to electrophoresis through a $6 \%(\mathrm{w} / \mathrm{v})$ non-denaturing polyacrylamide gel, and the dried gel was exposed to $\mathrm{X}$-ray film (X-OMAT AR5; Kodak, Rochester, NY) for $45 \mathrm{~min}$ (18S) or $2 \mathrm{~h}$ (ER). Relative band densities were determined by scanning densitometry (IS1000 Digital Imaging System; San Leandro,
CA), and results were expressed as the ratio of ER:18S band densities.

For the ePR RPA, plasmid containing the ePR HBD cDNA (ePR3.3) was purified by FPLC and linearized with the restriction enzyme Rsa I. An ePR antisense cRNA probe was then synthesized as described earlier using $500 \mathrm{ng}$ of the Rsa I linearized ePR HBD (designed to protect a fragment of 273 nucleotides; specific activity $6.41 \times 10^{8}$ d.p.m. $\mu^{-1}$ cRNA). The $18 \mathrm{~S}$ rRNA was used as an internal control (specific activity $1.01 \times 10^{8}$ d.p.m. $\mu g^{-1}$ cRNA). Probes were purified by non-denaturing gel electrophoresis, and hybridization was performed as described earlier. Digestion of nonhybridized mRNA and cRNA probe was performed using

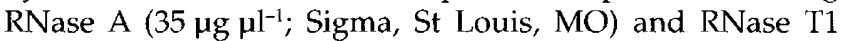
$\left(1.75 \mathrm{ng} \mathrm{l}^{-1}\right)$. Undigested transcripts were subjected to electrophoresis through a $6 \%$ native polyacrylamide gel, and the dried gel was exposed to X-ray film for 1 (18S) or 16 $(P R) h$. Relative absorbance densities of the bands were determined by scanning densitometry; data were expressed as the ratio of PR:18S band densities.

\section{Radioimmunoassays}

Oestradiol and progesterone concentrations were determined by double antibody radioimmunoassay validated in this laboratory (McDowell et al., 1995; oestradiol: Diagnostic Products Corp., Los Angeles, CA; progesterone: Pantex Corp., Santa Monica, CA). For each hormone, all samples from a single season of Expt 1 were analysed in one assay. All of the samples from Expt 2 were analysed in a single assay. Mean hormone values for serum samples taken every $6 \mathrm{~h}$ for $24 \mathrm{~h}$ before biopsy were used for analyses to account for the variability in serum hormone concentrations when steroids are administered exogenously in oil (McDowell et al., 1987). Intra-assay coefficients of variation $(\mathrm{CV})$ for the three oestradiol assays were $13 \%$ (Expt 1, first season), $12 \%$ (Expt 1 , second season) and $8 \%$ (Expt 2). Intra-assay CV for the three progesterone assays were $5.0 \%$ (Expt 1, first season), $5.5 \%$ (Expt 1, second season) and $1.8 \%$ (Expt 2). Interassay $\mathrm{CV}$ were $7 \%$ for oestradiol and $6 \%$ for progesterone. Assay sensitivities were 1 and $20 \mathrm{pg}$ per tube for oestradiol and progesterone, respectively.

\section{Statistical analyses}

Experiment 1. Relative band densities for 18S rRNA in all assays were analysed by one-way ANOVA using the general linear models procedure of the Statistical Analysis System (SAS Institute, 1996) to confirm that the amount of transcripts for this gene did not vary among the treatment groups and could, therefore, serve as an internal control for all samples. Relative amounts of PR mRNA (expressed as the ratios of the relative band densities for PR mRNA:18S rRNA) were analysed by ANOVA. When the overall ANOVA $F$ tests were significant, planned comparisons were performed on treatment means. Data for the abundance of PR mRNA are presented as the mean \pm SEM. The relative abundance of ER mRNA (expressed as the ratio of ER mRNA:18S rRNA band 
densities) was determined to have heterogeneity of variance, that is, the variability was not equal for each group. Because heterogeneity of variance invalidates the assumptions of ANOVA, the ER data were subjected to natural logarithmic transformations (Sokal and Rohlf, 1969). The transformed data were determined not to have heterogeneous variances and, therefore, were analysed by ANOVA. When the ANOVA was significant, differences among treatment means were determined by planned comparisons. If no differences were detected across all days, data for non-mated mares and pregnant mares were tested in separate analyses. Data for ER mRNA are presented as the anti-natural logarithm of the treatment means with the $95 \%$ confidence intervals around those means, as appropriate for transformed data (Sokal and Rohlf, 1969).

Serum oestradiol and progesterone concentrations were analysed by ANOVA and planned comparisons as described earlier. For the purpose of statistical analysis, if a hormone concentration fell below the sensitivity of the assay, it was assigned a value of one-half the assay sensitivity. Data for serum oestradiol and progesterone concentrations are presented as the mean \pm SEM.

Experiment 2. Relative abundance of endometrial PR and ER mRNAs, and serum concentrations of oestradiol and progesterone were analysed by ANOVA using SigmaStat version 2.0 (Kuo et al., 1992). Data for the relative abundance of ER mRNA were determined to have heterogeneity of variance and were subjected to natural logarithmic transformations as described for Expt 1. When the overall ANOVA $F$ tests were significant, differences among treatment groups were compared by Bonferroni's $T$ tests (power set to $\alpha=0.05$ ). Data are presented as described for Expt 1.

\section{Results}

\section{Cloning the equine oestrogen and progesterone receptor} cDNAs

The eER HBD (eER 13.3) was subcloned by PCR from a $4000 \mathrm{bp}$ eER cDNA (eER 13) isolated from the equine oestrous endometrial cDNA library. The resulting 377 nucleotide sequence (excluding the PCR primer sequences) shared 93, 90, 91 and 94\% nucleotide and 95, 98, 98 and $96 \%$ deduced amino acid identities with human, rat, mouse and sheep ER HBD cDNAs, respectively. By comparison with other known ER sequences, it was determined that the clones obtained were the equine ER $\alpha$ subunit. The GenBank accession no. for the resulting sequence is AF007799.

The oestrous endometrial cDNA library was also screened for ePR. The sequence for 1307 nucleotides of the $5^{\prime}$ end of the longest ePR cDNA clone (ePR7) was determined. This ePR clone contained two putative translation start sites that corresponded to translation initiation sites for human PR forms $\mathrm{A}$ and $\mathrm{B}$, and the nucleotide sequence in the coding region was $78 \%$ homologous with that of the human PR (Kastner et al., 1990). Nucleotide sequences (354 bp) of two ePR HBD regions were identical and shared 92, 81, 90, 82 and
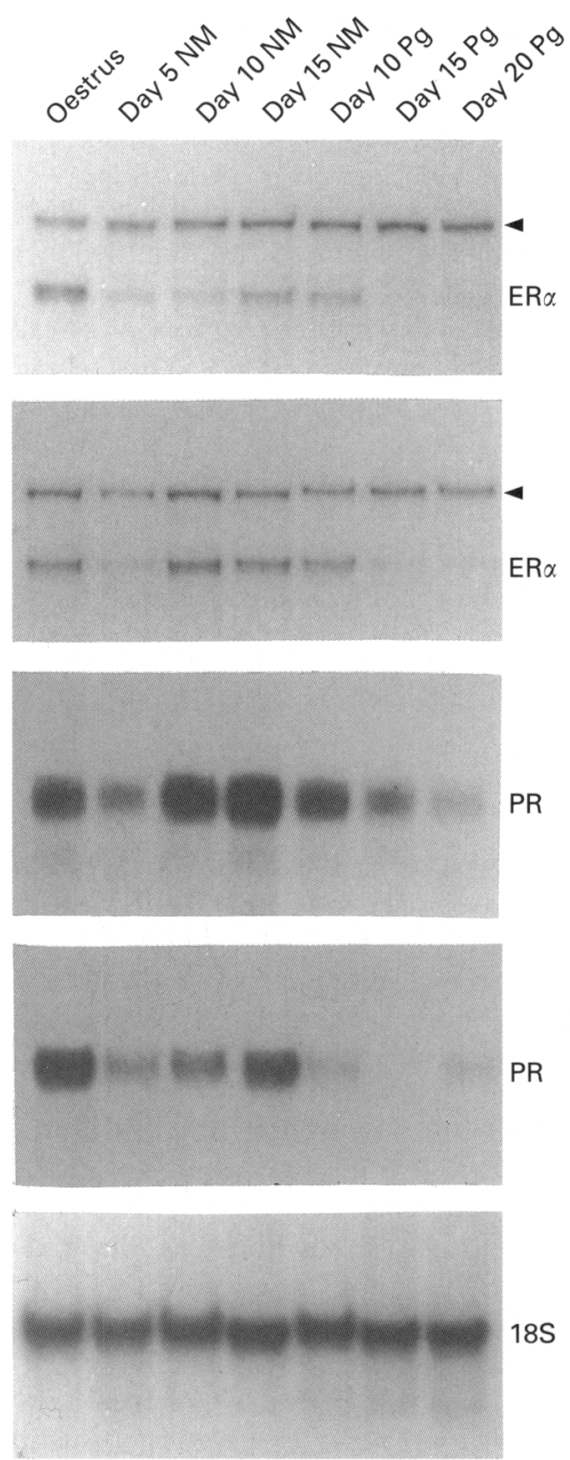

Fig. 1. Representative autoradiograms from ribonuclease protection assays of equine endometrial RNA showing protected fragments for oestrogen receptor $(\mathrm{ER} \alpha)$, progesterone receptor (PR) and $18 \mathrm{~S}$. Arrowheads indicate the non-specific band present when samples were hybridized with the ER $\alpha$ cRNA probe. Samples loaded into each lane are from mares in oestrus, days 5,10 or 15 after ovulation in non-mated cycles (NM) or days 10, 15 or 20 of pregnancy $(\mathrm{Pg})$.

$90 \%$ nucleotide and 95, 91, 95, 97 and 95\% deduced amino acid identities with human, mouse, rabbit, rat and sheep PR HBD cDNAs, respectively. The GenBank accession no. for the 5' sequence of ePR7 is AF053141 and for the ePR3.3 clone is AF007798.

\section{Ribonuclease protection assays}

The ER $\alpha$ and PR hybridizations for all equine endometrial samples resulted in protected bands of the expected sizes (324 and.273 nucleotides, respectively) as well as a larger, 
Table 1. Significance levels of planned comparisons for the abundance of equine endometrial oestrogen (ER $\alpha$ ) and progesterone receptor (PR) mRNAs and circulating oestradiol and progesterone concentrations for Expt 1

\begin{tabular}{lcccc}
\hline Comparison & ER & PR & Oestradiol & Progesterone \\
\hline Oestrus = day 5 NM = day 10 NM = day 15 NM & $0.2886^{\mathrm{a}}$ & 0.0058 & 0.0112 & 0.0001 \\
Oestrus versus day 5 to day 15 NM & & 0.0106 & 0.0030 & 0.0005 \\
Oestrus versus day 5 NM & & 0.0007 & 0.0069 & 0.0002 \\
Oestrus versus day 10 NM & & 0.0648 & 0.0021 & 0.0001 \\
Oestrus versus day 15 NM & 0.0001 & 0.3197 & 0.0706 & 0.3690 \\
Oestrus = day 10 Pg = day 15 Pg = day 20 Pg & 0.0001 & 0.0001 & $0.2975^{\mathrm{a}}$ & 0.0037 \\
Oestrus versus day 10 to day 20 Pg & 0.0250 & 0.0066 & & 0.0003 \\
Oestrus versus day 10 Pg & 0.0001 & 0.0020 & & 0.0027 \\
Oestrus versus day 15 Pg & 0.0001 & 0.0002 & & 0.0012 \\
Oestrus versus day 20 Pg & 0.3741 & 0.3315 & 0.1777 & 0.0034 \\
Day 10 NM versus day 10 Pg & 0.0001 & 0.0259 & 0.6365 & 0.0094 \\
Day 15 NM versus day 15 Pg & & & & \\
\hline
\end{tabular}

NM: non-mated; Pg: pregnant.

Values indicate significance level of $P$ (for example, $P=0.2886$ ).

"These comparisons were not significant, therefore, individual comparisons were not performed.

(a)

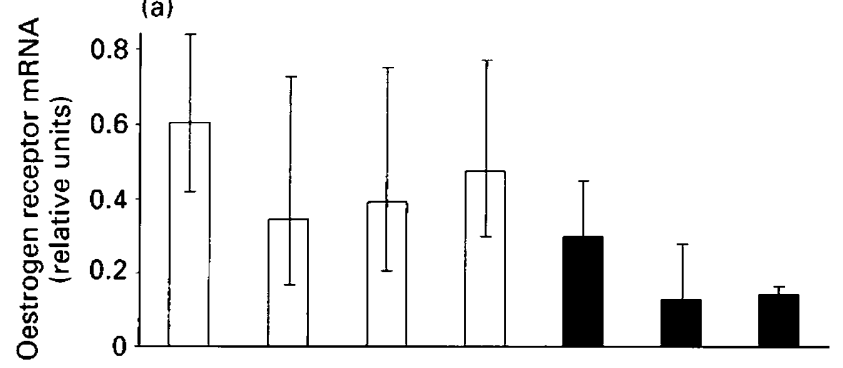

(c)

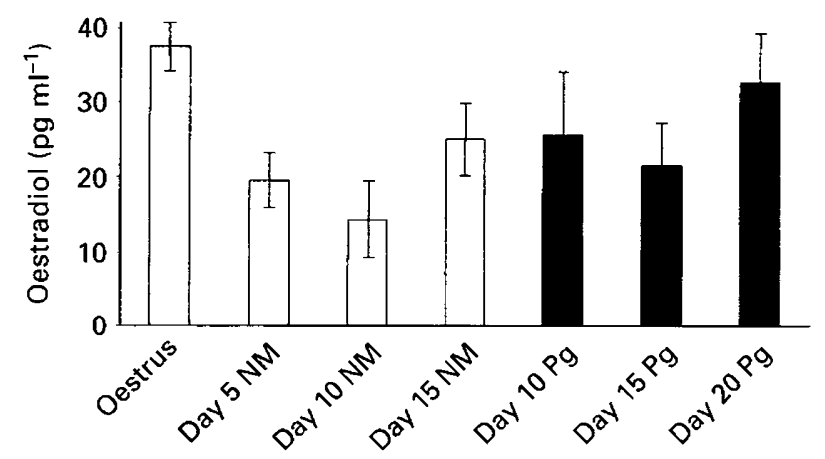

Day of cycle or pregnancy (b)
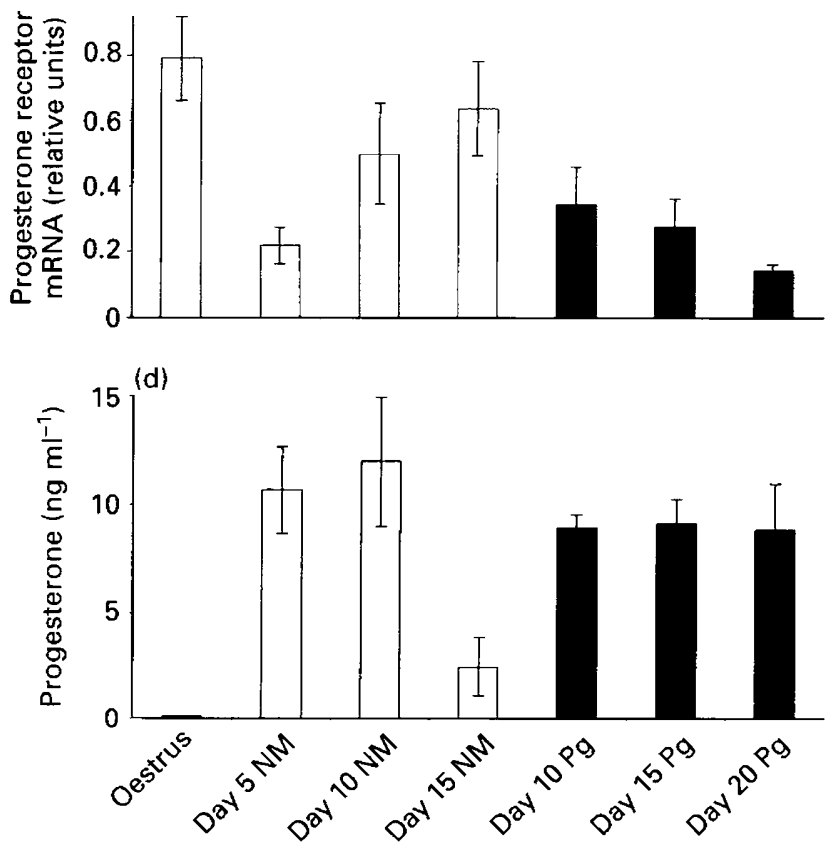

Day of cycle or pregnancy

Fig. 2. (a) Endometrial oestrogen receptor ( $E R \alpha)$ mRNA (mean $\pm 95 \%$ confidence interval), (b) endometrial progesterone receptor (PR) mRNA (mean \pm SEM), (c) peripheral circulating oestradiol concentrations (mean \pm SEM) and (d) peripheral circulating progesterone concentrations (mean \pm SEM) for mares at oestrus, on days 5, 10 or 15 after ovulation in non-mated (NM) cycles ( $\square$ ), and on days 10,15 and 20 of pregnancy $(\mathrm{Pg} ; \mathbf{D})$ in Expt 1 . Statistical analysis was performed on the amount of steroid receptor mRNA or hormone concentration (that is within each of (a), (b), (c) or (d)). When indicated by a significant overall $F$ test, the amount of receptor or hormone concentration for individual days of the non-mated cycles or pregnancy were compared with values obtained at oestrus by planned comparisons. In addition, values for each hormone receptor or serum concentration for days 10 and 15 were compared between non-mated cycles and pregnancy. Significance levels of these planned comparisons are shown in Table 1.

non-specific band that was also present in the ER $\alpha$ hybridized yeast tRNA (negative control) (Fig. 1). The $18 \mathrm{~S}$ hybridization also resulted in a band of the expected size ( 80 nucleotides), and abundance of the $18 \mathrm{~S}$ transcript was not different among treatment groups.

\section{Experiment 1}

Results from Expt 1 are summarized (Fig. 2 and Table 1). There was an overall effect of day on the amount of both ER $\alpha$ $(P=0.0001)$ and PR $(P=0.0014)$ mRNAs. In non-mated mares, 
(a)

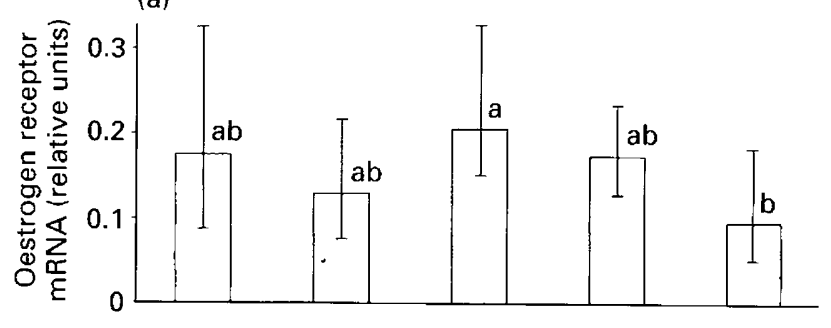

(c)

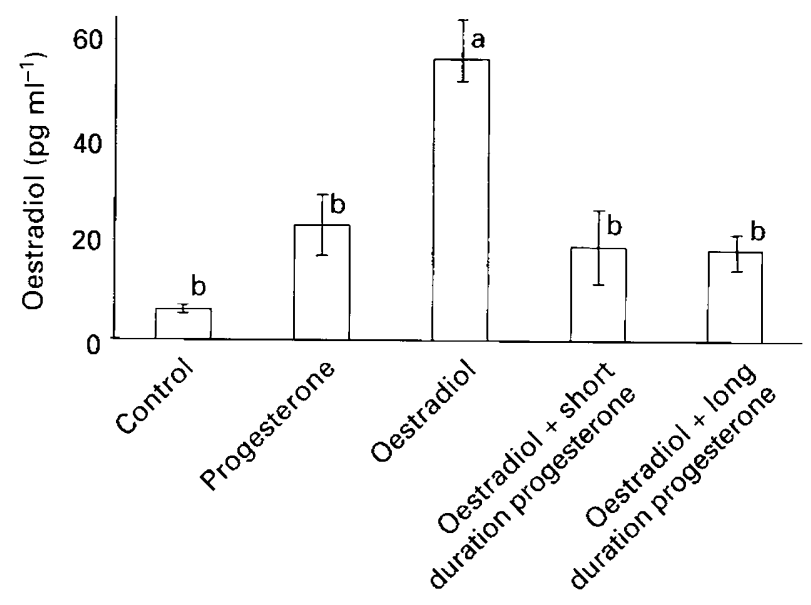

Steroid treatment (b)

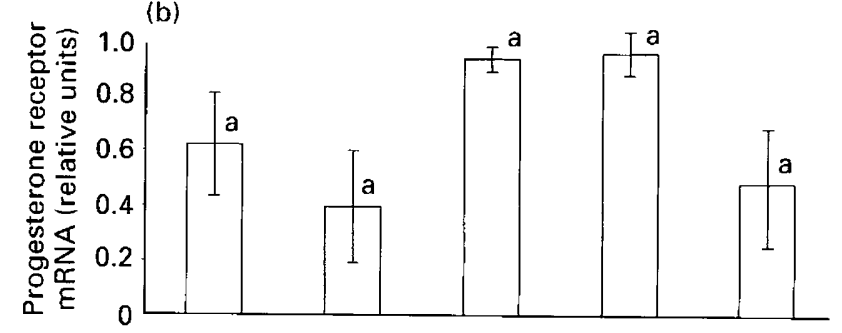

(d)

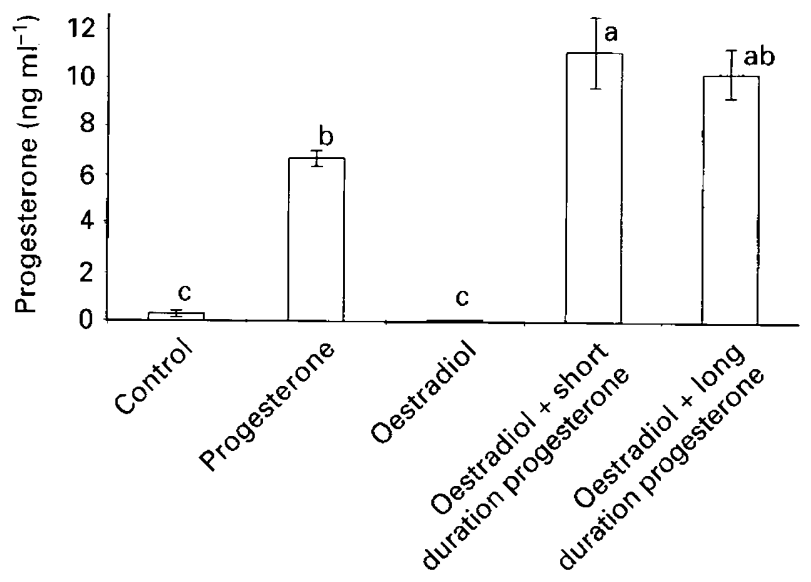

Steroid treatment

Fig. 3. (a) Endometrial oestrogen receptor (ER $\alpha$ ) mRNA (mean $\pm 95 \%$ confidence interval), (b) endometrial progesterone receptor (PR) mRNA (mean \pm SEM), (c) peripheral circulating oestradiol concentrations (mean \pm SEM) and (d) peripheral circulating progesterone concentrations (mean \pm SEM) for mares in the following steroid treatment groups: control (vehicle treated); progesterone alone; oestradiol alone; oestradiol priming followed by short duration progesterone; and oestradiol priming followed by long duration progesterone. Values for each group were compared within each of (a), (b), (c), and (d). Means with the same letter are not significantly different. Means with different letters are significantly different $(P<0.05)$.

ER $\alpha$ mRNA content was similar during oestrus and on days 5,10 or 15 of the cycle. In contrast, PR mRNA content was increased at oestrus, decreased at day 5, and increased to approach oestrous values at day 15 of the cycle. The amount of both ER $\alpha$ and PR mRNA was significantly higher at oestrus than for each day of pregnancy tested. When pregnant and non-mated groups were compared within day, the abundance of receptor message was similar at day 10 , but was significantly lower at day 15 of pregnancy for both ER $\alpha$ and PR mRNAs.

There were no differences in serum oestradiol concentrations when tested across all days. However, when non-mated and pregnant mares were examined in separate analyses, there was an effect of day in non-mated mares $(P=0.0112)$, and mean comparisons revealed that oestradiol concentrations were higher at oestrus than at days 5 or 10 of the non-mated cycles. Serum oestradiol concentrations were not different among days 10,15 or 20 of pregnancy when compared with oestrous concentrations. There was an overall effect of day on serum progesterone concentrations $(P=0.0003)$; progesterone concentrations were lower at oestrus and at day 15 of the non-mated cycles than at any other day tested. When pregnant and non-mated groups were compared within day, serum progesterone concentrations were higher at day 15 of pregnancy than during the non-mated cycles.

\section{Experiment 2}

Results from Expt 2 are summarized (Fig. 3). When anoestrous mares were treated with exogenous steroids, there was an overall effect of treatment on amount of ER $\alpha$ mRNA $(P=0.0420)$. Oestradiol treatment alone resulted in an increase $(P<0.05)$ in the abundance of ER $\alpha$ mRNA in equine endometrium compared with oestradiol priming followed by long duration progesterone. There were no significant differences among the remaining treatment groups. There were no differences in the amount of endometrial PR mRNA among treatment groups when anoestrous mares were treated with exogenous steroids. However, the amount of PR tended to be higher in the groups treated with oestradiol alone and oestradiol and short duration progesterone.

Before initiation of treatment, oestradiol concentrations were $\leq 7 \mathrm{pg} \mathrm{ml}^{-1}$, and progesterone concentrations were $<1 \mathrm{ng} \mathrm{ml}^{-1}$ in all mares. After treatment with exogenous steroids, there was an overall effect of treatment $(P=0.0004)$ on peripheral oestradiol concentrations. Oestradiol concentrations were higher $(P<0.05)$ for mares given oestradiol only for 6 days, than for any other treatment group, but there were no differences among the remaining treatment groups. There was also an overall treatment effect $(P=0.0001)$ on 
circulating progesterone concentrations; differences among treatment groups are shown (Fig. 3).

\section{Discussion}

In this study, the equine ER $\alpha$ and PR cDNAs were cloned from an equine oestrous endometrial CDNA library, and the hormone binding domains were sequenced. In addition, the 5 ' end of the longest ePR clone was sequenced and revealed translation initiation sites for both the A and B forms of this steroid receptor. The resulting clones were used in ribonuclease protection assays to determine how the amount of oestrogen and progesterone receptor mRNAs changes throughout the oestrous cycle and early pregnancy, and in mares supplemented with exogenous steroids. The abundance of both ER $\alpha$ and PR mRNAs in the endometrium was affected by the day of the oestrous cycle or pregnancy. Compared with oestrus, the amount of ER $\alpha$ mRNA was not different in the non-mated cycles, but was significantly lower during early pregnancy. Similarly, Watson et al. (1992) using immunohistochemistry, showed that staining intensities for ER protein in uterine epithelium were not affected by stage of the oestrous cycle. However, there were no differences in ER protein content between pregnant and non-pregnant mares at day 14 after ovulation. It is possible that the immunocytochemical technique did not discriminate between the $\alpha$ and $\beta$ forms of the oestrogen receptor. In the present study, which measured $E R \alpha$, there was no difference in the abundance of mRNA between pregnant and non-pregnant mares at day 10 after ovulation, but the amount was lower at day 15 of pregnancy compared with day 15 of dioestrus. The differences in these studies may also reflect differential regulation by post-transcriptional mechanisms similar to that reported in sheep (Ing et al., 1993).

Horse (Flood et al., 1979; Zavy et al., 1979; Marsan et al., 1987; Goff et al., 1993a) and pig (Bazer et al., 1986; Geisert et al., 1990) conceptuses synthesize and secrete oestrogens during early development. Conceptus oestrogens are a primary signal for maternal recognition of pregnancy in pigs (Bazer et al., 1986; Geisert et al., 1990) but are not likely to be a primary signal in horses (Goff et al., 1993b). Geisert et al. (1993) reported that the abundance of ER mRNA in endometrial homogenates from cyclic and pregnant gilts was greatest on day 10 and decreased by day 15 . Similar to data from the present study in mares, endometrial ER mRNA increased on day 18 in cyclic gilts, but the increase was not detectable on day 18 in pregnant gilts. Immunohistochemical analyses indicated that ER protein was maintained in surface epithelium after day 12 of pregnancy in gilts, at a time when conceptus oestrogens could influence uterine function in this species (Geisert et al., 1993). Although conceptus oestrogens do not appear to regulate luteal maintenance in mares (Goff et al., 1993a), it is likely that conceptus oestrogens, acting via endometrial ERs, do influence uterine function in a manner that remains to be elucidated. The decrease in the abundance of ER $\alpha$ mRNA by day 15 of pregnancy compared with day 15 of the oestrous cycle may be due to differences in the duration of exposure of the uterine endometrium to progesterone. Indeed, a period of progesterone dominance affecting tuterine response to oestrogens has been well characterized in the endometrium of ewes (McCracken et al., 1984).

In general, progesterone downregulates expression of its own receptor (Kraus and Katzenellenbogen, 1993). In the present study, the abundance of PR mRNA decreased from oestrus to early dioestrus, and increased by late dioestrus. Reports that PR binding sites were lower during the luteal phase and early pregnancy than at oestrus (Tomanelli et al., 1991; Nobelius, 1992; Watson et al., 1992; Re et al., 1995) support the changes in the abundance of PR mRNA observed in the present study. These changes appear to be in preparation for the next ovulation (Nobelius, 1992) and are similar to patterns of PR mRNA expression reported for ewes (Spencer and Bazer, 1995) and pigs (Geisert et al., 1994). The results of the present study show that the amount of PR mRNA was lower at day 15 after ovulation in pregnant mares than in non-mated mares, and continued to be low until at least day 20 of pregnancy. In contrast, PR protein content of the mare uterus, when measured by immunocytochemistry or protein binding assays, was lower at day 14 or 15 of pregnancy than during oestrus, but was not different from that at dioestrus (Tomanelli et al., 1991; Nobelius, 1992; Watson et al., 1992). Similarly, in pregnant ewes, the amount of PR mRNA and protein did not always change in a coordinated manner (Ott et al., 1993).

When anoestrous mares were treated with exogenous steroids, oestradiol treatment for 6 days increased the endometrial content of its own receptor mRNA compared with oestradiol priming for 6 days followed by progesterone for 12 days. There was no difference in the amount of ER $\alpha$ mRNA in mares treated with oestradiol alone for 6 days compared with mares treated with oestradiol for 6 days followed by progesterone for 6 days. Therefore, it is likely that the duration of progesterone dominance affected ER $\alpha$ mRNA content in equine uterine endometrium. Similarly, when ovariectomized ewes were given oestradiol for 2 days, progesterone for 10 days, or progesterone for 10 days with oestradiol administered on the final 2 days of progesterone treatment, the amount of ER mRNA increased with oestradiol treatment alone, while in ewes treated with progesterone alone or progesterone with oestradiol, the amount was similar to control ewes (Wu et al., 1996).

In contrast to the results in normally cyclic or pregnant mares, in which the amount of PR mRNA changed with fluctuating circulating steroid concentrations, the amount of PR mRNA did not vary significantly when anoestrous mares were treated with exogenous steroids. The reasons for this apparent dichotomy are not clear; however, it is possible that factors other than oestradiol and progesterone are involved in the regulation of PR gene expression in the endometrium of mares. It is also possible that previous steroid exposure affects the abundance of steroid receptor mRNA. Even though the anoestrous mares were exposed to 6 days of oestradiol priming before initiation of progesterone treatment, the cyclic and pregnant mares were exposed to several 'cycles' of changing oestrogen and progesterone concentrations in the course of the normal breeding season before initiation of the experiment.

In summary, this study demonstrated that the abundance of steroid receptor mRNAs changes with the fluctuating 
steroid environment in the uterine endometrium of cyclic and early pregnant mares. In general, the amount of both $\mathrm{ER} \alpha$ and PR mRNAs increased during oestrus and late dioestrus, as mares prepared for the next oestrous cycle. However, mRNAs for both types of receptor decreased with increasing days of pregnancy and sustained circulating progesterone concentrations. The amount of steroid receptor mRNA was relatively high in the control group of anoestrous mares. This may represent the constitutive level of gene transcription for these receptors. The changes in the amount of ER $\alpha$ and PR mRNAs were not as marked in anoestrous mares treated with exogenous oestradiol and progesterone as those in normally cyclic mares. It is likely that factors other than circulating oestradiol and progesterone concentrations regulate $E R \alpha$ and PR gene expression.

This research was supported in part by the University of Kentucky Equine Research Foundation and a grant from the Lucille P. Markey Charitable Trust. This report (No 98-14-202) is published as part of a project of the Kentucky Agricultural Experiment Station with the approval of the director. The authors wish to express their appreciation to Lynn Ennis, Barry Curd and their staff for assistance in animal care and handling, to Jim Hyde for assistance with FPLC purification of the cDNAs in plasmid, and to Matt Barker for assistance with the statistical analyses. The rat ER and PR CDNA probes were generously provided by Ok-Kyong Park-Sarge, University of Kentucky.

\section{References}

Adams MH, Sullivan ND, Behrendt CY, Daniel KS and McDowell KJ (1997) Molecular cloning of the estrogen and progesterone receptors from equine endometrium Biology of Reproduction 56 Supplement 1153 (Abstract)

Bazer FW, Vallet JL, Roberts RM, Sharp DC and Thatcher WW (1986) Role of conceptus secretory products in establishment of pregnancy lournal of Reproduction and Fertility 76 841-850

Bracher V, Mathias S and Sheldrick L (1991) Oestrogen and progesterone receptor concentrations in the endometrium of normal and subfertile mares Journal of Reproduction and Fertility Abstract Series 773 (Abstract)

Chomczynski P and Sacchi N (1987) Single-step method of RNA isolation by acid guanidinium thiocyanate-phenol-chloroform extraction Analytical Biochemistry $162156-159$

Davis LG, Kiehl WM and Battey JF (1994) Basic Methods in Molecular Biology 2nd Edn Appleton \& Lange, Norwalk, CT

Flood PF, Betteridge KJ and Irvine DS (1979) Oestrogens and androgens in blastocoelic fluid and cultures of cells from equine conceptuses of 10-22 days gestation Journal of Reproduction and Fertility Supplement 27 413-420

Geisert RD, Zavy MT, Moffatt RJ, Blair RM and Yellin T (1990) Embryonic steroids and the establishment of pregnancy in pigs fournal of Reproduction and Ferility Supplement 40 293-305

Geisert RD, Brenner RM, Moffatt RJ, Harney JP, Yelin T and Bazer FW (1993) Changes in oestrogen receptor protein, mRNA expression and localization in the endometrium of cyclic and pregnant gilts Reproduction, Fertility and Development 5247-260

Geisert RD, Pratt TN, Bazer FW, Mayes JS and Watson GH (1994) Immunocytochemical localization and changes in endometrial progestin receptor protein during the porcine oestrous cycle and early pregnancy Reproduction, Fertility and Development $6749-760$

Goff AK, Leduc S, Pitras P and Vaillancourt D (1993a) Steroid synthesis by equine conceptuses between days 7 and 14 and endometrial steroid metabolism Domestic Animal Endocrinology $10229-236$
Goff AK, Sirois J and Pontbriand D (1993b) Effect of oestradiol on oxytocinstimulated prostaglandin $\mathrm{F} 2 \alpha$ release in mares Journal of Reproduction and Fertility 98 107-112

Ing NH, Tsai SY and Tsai M-J (1993) Progesterone and estrogen. In Genes in Mammalian Reproduction 271-291 Ed. RBL Gwatkin. Wiley-Liss Inc., New York

Kastner P, Krust A, Turcotte B, Stropp U, Tora L, Gronemeyer H and Chambon P (1990) Two distinct estrogen-regulated promoters generate transcripts encoding the two functionally different human progesterone receptor forms $A$ and $B E M B O$ Journal 9 1603-1614

King RJB (1997) Structure and function of steroid receptors Journal of Endocrinology 114 341-349

Kraus WL and Katzenellenbogen BS (1993) Regulation of progesterone receptor gene expression and growth in the rat uterus: modulation of estrogen actions by progesterone and sex steroid hormone antagonists Endocrinology 132 2371-2379

Kuo J, Fox E and McDonald S (1992) SigmaStat for DOS User's Manual 1 Jandel Scientific Software, San Rafael, CA

McCracken JA, Schramm W and Okulicz WC (1984) Hormone receptor control of pulsatile secretion of $\mathrm{PGF}_{2,1}$ from the ovine uterus during luteolysis and its abrogation in early pregnancy Animal Reproduction Science 731-55

McDowell KJ, Sharp DC and Grubaugh W (1987) Comparison of progesterone and progesterone + oestrogen on total specific uterine proteins in pony mares Journal of Reproduction and Fertility Supplement 35 335-342

McDowell KJ, Adams MH, Franklin KM and Baker CB (1995) Changes in equine endometrial retinol-binding protein RNA during the estrous cycle and early pregnancy and with exogenous steroids Biology of Reproduction $\mathbf{5 2}$ 438-443

Mangelsdorf DJ, Thummel C, Beato $M$ et al. (1995) The nuclear receptor superfamily: the second decade Cell 83 835-839

Marsan C, Goff AK, Sirois J and Betteridge KJ (1987) Steroid secretion by different cell types of the horse conceptus Journal of Reproduction and Fertility Supplement 35363-369

Morelle G (1989) A plasmid extraction procedure on a miniprep scale Gibco Focus 11 7-8

Nobelius AM (1992) Gestagens in the Mare: An Appraisal of the Effects of Gestagenic Steroids on Suppression of Oestrus in Mares Master of Reproductive Science Thesis, Monash University, Melbourne, Victoria

Ott TL, Zhou Y, Mirando MA, Stevens C, Harney JP, Ogle TF and Bazer FW (1993) Changes in progesterone and oestrogen receptor mRNA and protein during maternal recognition of pregnancy and luteolysis in ewes Journal of Molecular Endocrinology 10 171-183

Parker MG (1990) Mechanisms of action of steroid receptors in the regulation of gene transcription Journal of Reproduction and Fertility 88 717-720

Re G, Badino P and Novelli A (1995) Distribution of cystolic oestrogen and progesterone receptors in the genital tract of the mare Research in Veterinary Science 59 214-218

SAS Institute (1996) SAS User's Guide: Statistics Version 6 2nd Edn Statistical Analysis System, Inc., Cary, NC

Sokal RR and Rohlf FJ (1969) Biometry W.H. Freeman and Co., San Francisco, CA Spencer TE and Bazer FW (1995) Temporal and spatial alterations in uterine estrogen receptor and progesterone receptor gene expression during the estrous cycle and early pregnancy Biology of Reproduction 53 1527-1543

Tomanelli RN, Sertich PL and Watson ED (1991) Soluble oestrogen and progesterone receptors in the endometrium of the mare Journal of Reproduction and Fertility Supplement 44 267-273

Watson ED, Skolnik SB and Zanecosky HG (1992) Progesterone and estrogen receptor distribution in the endometrium of the mare Theriogenology 38 $575-580$

Wu WX, Owiny J, Zhang Q, Ma XH and Nathanielsz PW (1996) Regulation of the estrogen receptor and its messenger ribonucleic acid in the ovariectomized sheep myometrium and endometrium: the role of estradiol and progesterone Biology of Reproduction 55 762-768

Zavy MT, Mayer R, Vernon MW, Bazer FW and Sharp DC (1979) An investigation of the uterine luminal environment of non-pregnant and pregnant pony mares Journal of Reproduction and Fertility Supplement 27 $403-411$ 